\title{
"Music" For Youth During the Covid-19 Pandemic
}

\author{
Nita Arisanti Yulanda ${ }^{1, a)}$, Suhendri ${ }^{2}$, Keti Andriani ${ }^{2}$, and Riszky Safitri ${ }^{2}$ \\ ${ }^{1}$ Professional Study Program, Faculty of Medicine, University of Tanjungpura \\ ${ }^{2}$ Nursing Study Program, Faculty of Medicine, University of Tanjungpura \\ a)Coressponding Author: nita.arisantiyulianda@ners.untan.ac.id
}

\begin{abstract}
SARS-CoV-2 virus was found to be targeted cells may be located in the lower respiratory tract, COVID-19 infection can cause mild, moderate to severe symptoms. The main symptoms that appear are fever (> $38^{\circ} \mathrm{C}$ ), cough and difficulty breathing. Vitamin $\mathrm{C}$ treatment has an antiviral effect. Clinical trials have shown that administering high doses of vitamin $\mathrm{C}$ has a beneficial effect against colds. As a nurse, one of the roles as an extension agent can be carried out in handling Covid-19 patients, namely providing communication, information, and education about health to the community. The role of nurses in providing education to the community is very necessary because it can make people who are given education understand the information conveyed. In this Community Service activity, the focus is on teenagers as one of the preventive efforts against the transmission of the Covid-19 virus through the provision of Health Education on the importance of consuming vitamin $\mathrm{C}$ according to the needs of the adolescent body.
\end{abstract}

Keywords: Vitamin C, Adolescents, Covid-19

\section{INTRODUCTION}

Severe Acute Respiratory Syndrome Corona Virus 2 (SARS-CoV-2) which is currently known as COVID-19 (Coronavirus Disease 2019) is sweeping all over the world, even WHO has announced on December March 11, 2020 cases of COVID-19 as a global pandemic (yang, et al.,2020). The increase in cases occurred due to human-to-human transmission through aerosol, droplet and fecal-oral transmission (Rothan \& Byraredy, 2020).

The SARS-CoV-2 virus was found to target cells possibly located in the lower respiratory tract (Chen et al., 2020). The SARS-CoV-2 virus uses ACE-2 (Angiotensin converting enzyme 2) as a receptor, similar to that of SARS CoV. The sequence of the RBD (receptor-binding domain) including the RBM (receptor-binding motif) in SARS-CoV-2 is in direct contact with the enzyme ACE-2 (angiotensin-converting enzyme 2). Residual results in SARS-CoV-2 RBM interact with ACE 2 in humans, thereby increasing the capacity of SARS-CoV- to infect human cells. COVID19 infection can cause mild, moderate to severe symptoms. The main symptoms that appear are fever $\left(>38^{\circ} \mathrm{C}\right)$, cough and difficulty breathing. In severe cases the deterioration occurs rapidly and progressively.

Word of Meters conveyed data as of May 31, 2021 morning, the number of COVID-19 cases reached 171,006,105 cases and Indonesia was in the top 20 COVID-19 cases in Asia (Mulya, 2021). Meanwhile, according to data from the COVID-19 Task Force in Indonesia, the number of active cases is 101,639 cases. In May 2021, West Kalimantan experienced a decrease in active cases recorded on May 9, 2021 by $12.59 \%$, decreasing to $6.64 \%$ on May 30, 2021 (SATGAS COVID-19, 2021). Although the percentage of active cases in the month of May declined, but people still have to maintain the system Immune and adhered protocol health $5 \mathrm{M}$ (Wear the masks, wash the hands, keep the distance, away from the crowds and limit the mobility)

As a nurse has one role as an educator, as stipulated in the Act -Law (Law) Number 38 of 2014 concerning Nursing. These roles include nursing care, counseling and counselors, managers, researchers, and executor of tasks in the delegation of authority and circumstances of limitations. One of the roles that nurses can carry out in handling Covid-19 patients is one of the roles in providing communication, information, and education (IEC) about health to the community. The role of nurses in providing education to the community is very necessary 
because it can make people who are given education understand the information conveyed (Nursalam, 2021). The education that can be provided aims to help break the chain of spread of COVID-19 through the Health Protocol Disciplinary Movement and counseling on vitamin C consumption to increase immunity so that it is not easy to contract the disease. Vitamin C treatment has an antiviral effect. Clinical trials have shown that administering high doses of vitamin C has a beneficial effect against the common cold (Gorton \& Jarvis, 1999; Ran et al., 2018). Administration of high doses of vitamin $C$ (a dose of $1000 \mathrm{mg}$ vitamin $\mathrm{C}$ per hour for the first 6 hours and then 3 times daily for 3 days) treatment reduced flu and cold symptoms in patients when compared to the control group (Gorton \& Jarvis, 1999). A meta-analysis has shown that administering high doses of vitamin $C$ at the start of the common cold decreases the duration of the common cold and relieves symptoms, such as chest pain, fever, and chills (Ran et al., 2018). Vitamin $C$ is known to have antiviral effects, and high-dose treatment has shown beneficial effects in COVID-19 patients (Fowler et al., 2019) Increases antiviral cytokines, such as interferon (IFN)- $\alpha / \beta$ (Kim et al., 2013) Increases formation free radicals to decrease viral yield (Furuya et al., 2008) attenuating the exaggerated inflammatory response (Tripathi et al., 2007). Improve immune cell hyperactivation by changing energy metabolism (Kornberg et al., 2018). In this outreach activity, the team focused on teenagers, as one of the family members who also have a role in breaking the chain of transmission of the corona virus. As stated in PMK No. 28 of 2019 concerning the recommended nutritional adequacy rate for the Indonesian people states that the need for vitamin $C$ in adolescents aged (10-18 years) is $50-90 \mathrm{mg}$ for men, while $50-75$ mg for women (Ministry of Health, 2019).

Through health education to the community with the theme "Music" (Let's Consume Vitamin C) for Teenagers During the Covid-19 Pandemic, it can be a preventive effort for the community so that they are not susceptible to disease, especially during a pandemic.

\section{METHODS}

Activities are carried out online through Zoom Meetings. Community service activities are carried out through 6 stages, including

Stage 1. Determination of PKM Topics and Targets through field orientation activities, field orientation activities are carried out by observation from the environment where each PKM team lives by considering the affordability of participant network access because the activity will be carried out Online (On the Network);

Stage 2. Activities carried out at this stage are the PKM team determines the topic of PKM, the topic taken by the team seeks to invite the community to consume Vitamin $\mathrm{C}$, thus determining the title of PKM, namely "MUSIC" (Let's Consume Vitamin C) for Teenagers. Then proceed with the preparation of SAP (Counseling Events unit) which contains the objectives to be achieved during the activity, the method used is in the form of Podcasts with media instruments in the form of posters, descriptions of activity plans and evaluations to be carried out as well as materials to be provided during community service activities;

Stage 3. Deliberation. The activities carried out at this stage are deliberation, determining the contents of the instrument used, namely posters. The poster used explains the effect of Vitamin $C$ in boosting the immune system, the source of Vitamin $C$ and the recommended daily intake of Vitamin C;

Stage 4 participatory planning, at this stage the participants who will participate in Health Education activities have been determined, the schedule for implementation of activities and socialization of the mechanism for the activities to be carried out;

Stage 5. Implementation of Activities. At this stage the Community Service team carried out online activities with 27 youth participants, most of them are from Pontianak City and some participants are from North Kayong Regency, West Kalimantan. The method of activity is discussion, because the participants in this activity are teenagers who are expected not to feel bored during the PKM activity process. Before and after the activity, an evaluation of the knowledge of adolescents in consuming vitamin $C$ is carried out which consisted of 5 
questions;

Stage 6. Maintaining the sustainability of activities. This activity is expected not only for 1 (one) time but also can be preserved so that the PKM team can always remind the importance of consuming Vitamin C during the COVID-19 pandemic through the creation of educational videos uploaded on Instagram social media so that it can make it easier for the community, especially participants to know the importance of consuming Vitamin $\mathrm{C}$, especially during the COVID-19 pandemic.

\section{RESULTS}

Implementation of community service activities in the form of health education as one of the Health Education efforts to improve the immune system as an effort to prevent exposure to COVID-19. Health Counseling activities are carried out using the Online method, followed by 27 Youth Participants.

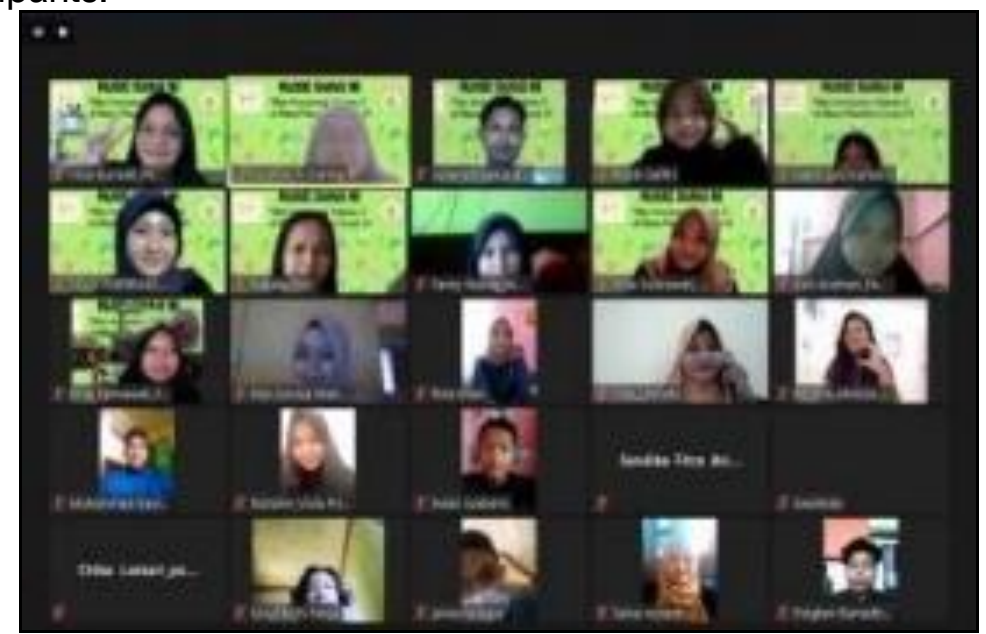

Figure 1. "Music" Health Extension Activities (Let's Take Vitamin C) To Teenagers During the COVID-19 Pandemic.

Before and after the health education was conducted, participants evaluated knowledge about vitamin $\mathrm{C}$ consumption using a google form with 5 types of closed questions, from the evaluation results obtained data values for 27 participants who answered correctly as follows:

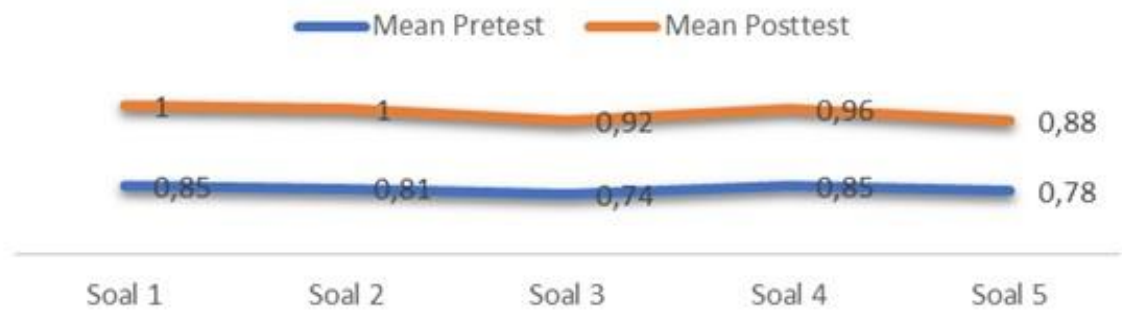

Figure 2. The results of the pretest-posttest mean of participants' knowledge about Vitamin $C$ consumption

Based on the picture above before and after After being given health education about Vitamin $\mathrm{C}$, there was an increase in the average score of participants who answered correctly the 5 questions given. The lowest mean value of the pretest results $(0.74)$ was on the question of how to consume vitamin C properly, and the highest average pretest result $(0.85)$ was regarding the definition of Vitamin $\mathrm{C}$ and the benefits of Vitamin $\mathrm{C}$ on immunity. In the post-test results, the lowest mean value was on the question of the impact of inappropriate consumption of Vitamin $C(0.88)$. Meanwhile, the highest change was in the average value of the pretest and posttest results on the question of food sources of vitamin $C(0.19)$.

\section{DISCUSSION}


The results of the study showed that there were some participants who still did not understand the explanation of Health education that had been given, especially in the third to fifth questions, from the post-test results there was still an average value under the instructor's expected value. As a nurse as stated (Nursalam, 2021) has three roles. The first role is to provide health information and education to the public regarding health problems, because with health education it is hoped that information will be conveyed to the public in a good and understandable manner. One of the information that can be conveyed is about prevention that can be done by the community. The second role is the ability of nurses to conduct rapid assessments of COVID-19 cases, so that an immediate determination can be made of the actions that must be taken by nurses and other health teams. The third role is a direct service provider for patients, this role is the main role for nurses because nurses must be able to meet the basic needs of patients even to a psychosocial approach for sufferers and families who often experience psychological problems such as fear, anxiety and even depression.

In this activity, nurses convey information about the importance of consuming vitamin $\mathrm{C}$ during a pandemic for adolescents, Vitamin C deficiency is associated with increased susceptibility to infection, and a weak immune response. People who are deficient in vitamin C are also believed to be more at risk of contracting the corona virus or Covid-19 disease because their immune system decreases. Vitamin $C$ is a micronutrient that plays an important role for humans. These powerful antioxidants are important for the production of collagen and carnitine which contribute to immune enhancement and defense. Even vitamin $C$ also acts as an antimicrobial agent that can fight various microorganisms that cause infection (Kim et al., 2013).

Vitamin $C$ is believed to be able to prevent and treat respiratory infections by increasing various immune cell functions. Research has also shown that giving vitamin $C$ to patients with acute respiratory infections can restore their plasma vitamin $C$ levels to normal, thereby improving the severity of the symptoms of the infection. The daily need for vitamin $\mathrm{C}$ depends on the age and gender of the person who consumes it (Lidia et al., 2020)

Several studies have proven the role of Vitamin $C$ for the body, especially during the COVID19 pandemic. Vitamin $C$ is not only able to accelerate the healing of patients with COVID-19, but also able to increase a person's immunity which can help prevent the occurrence of COVID-19. So as a nurse, she has a role as a provider of health education/information about education that can be done by the community to break the chain of transmission of COVID-19, one of which is by consuming Vitamin $\mathrm{C}$.

\section{CONCLUSION}

Coronavirus Disease 2019 (COVID-19) is a disease that is easily transmitted through the respiratory system. In order to break the chain of transmission, discipline from all levels of society is needed in implementing health protocols. In addition, health education from various health workers is still needed in increasing public knowledge. Health Education in maintaining the immune system, one example is by consuming enough Vitamin $\mathrm{C}$, that is expected to be able to increase the community's immune system so that it is not easy for disease transmission to occur.

\section{ACKNOWLEDGMENTS}

We express our gratitude to Allah Subhanahu Wa Ta'ala, because of the grace and guidance given so that this community service can run smoothly. This community service can be carried out properly with the support of (1) Dean of the Faculty of Medicine, Universitas Tanjungpura (2) Head of the Nursing Department (3) Head of the Nursing S1 Study Program (4) Coordinator of Health Promotion Program and (5) Student of the Nursing S1 Study Program. 


\section{REFERENCES}

Chen, N., Zhou, M., Dong, X., Qu, J., Gong, F., Han, Y., Qiu, Y., Wang, J., Liu, Y., Wei, Y. ., Xia, an, Yu, T., Zhang, X., \& Zhang, L. (2020). Articles Epidemiological and clinical characteristics of 99 cases of 2019 novel coronavirus pneumonia in Wuhan, China: a descriptive study. https://doi.org/10.1016/S0140-6736(20)30211-7

Fowler, AA, III, Truwit, JD, Hite, RD, Morris, PE, DeWilde, C., Priday, A., Fisher, B ., Thacker, LR, II, Natarajan, R., Brophy, DF, Sculthorpe, R., Nanchal, R., Syed, A., Sturgill, J., Martin, GS, Sevransky, J., Kashiouris, M. , ... Halquist, M. (2019). Effect of Vitamin C Infusion on Organ Failure and Biomarkers of Inflammation and Vascular Injury in Patients With Sepsis and Severe Acute Respiratory Failure: The CITRIS-ALI Randomized Clinical Trial. JAMA, 322(13), 1261.https://doi.org/10.1001/JAMA.2019.11825

Furuya, A., Uozaki, M., Yamasaki, H., Arakawa, T., Arita, M., \& Koyama, AH (2008). Antiviral effects of ascorbic and dehydroascorbic acids in vitro. International Journal of Molecular Medicine, 22(4), 541-545. https://doi.org/10.3892/lJMM 00000053

Gorton, HC, \& Jarvis, K. (1999). The effectiveness of vitamin C in preventing and relieving the symptoms of virus-induced respiratory infections. Journal of Manipulative \& Physiological Therapeutics, 22(8), 530-533. https://doi.org/10.1016/S0161-4754(99)70005-9

Kim, Y., Kim, H., Bae, S., Choi, J., Lim, SY, Lee, N., Kong, JM, Hwang, Y., Kang, JS, \& Lee, WJ (2013). Vitamin $C$ Is an Essential Factor on the Anti-viral Immune Responses through the Production of Interferon- $\alpha / \beta$ at the Initial Stage of Influenza A Virus (H3N2) Infection. Immune Network, 13(2), 70.https://doi.org/10.4110/IN.2013.13.2.70

Kornberg, M., P, B., PM, K., V, P., AM, S., N, P., PA, C., \& SH, S. (2018). Dimethyl fumarate targets GAPDH and aerobic glycolysis to modulate immunity. Science (New York, NY), 360(6387), 449-453. https://doi.org/10.1126/SCIENCE.AAN4665

Lidia, K., Levina, E., Setianingrum, S., Folamauk, C., Riwu, M., Lidesna, A., \& Amat, S. (2020 ). Health Improvement with Supplements and Balanced Nutrition in the Era of the Covid-19 Pandemic Journal of the Undana Community Service Institute, 14(2), 63-68. http://ejurnal.undana.ac.id/jlppm/article/view/3445

Minister of Health, R. (2019). recommended dietary allowances (RDA). In Regulation of the Minister of Health of the Republic of Indonesia concerning the RDA for the Indonesian Community. https://doi.org/10.1007/978-3-211-89836-9_1195

Mulya, PB (2021). World Covid-19 Update May 31, 2021: Indonesia ranks in the top 18 highest cases - Mind-Rakyat.com. https://www.mindedrakyat.com/internasional/pr011980438/update-covid-19-dunia-31-mei-2021-indonesiaoccupied-18-big-case

Nursalam. (2021). The Dilemma of the Role of Nurses during a Pandemic. https://www.jawapos.com/opin/09/04/2020/dilemma-peran-nur-perawat-during-pandemicl

Ran, L., Zhao, W., Wang, J., Wang, H., Zhao, Y., Tseng, Y., \& Bu, H. (2018). Extra Dose of Vitamin C Based on a Daily Supplementation Shortens the Common Cold: A Meta Analysis of 9 Randomized Controlled Trials. BioMed Research International, 2018. https://doi.org/10.1155/2018/1837634

SATGAS COVID-19, C. 19. (2021). INDONESIA COVID-19 DATA ANALYSIS.

Tripathi, P., P, T., L, K., \& V, S. (2007). The role of nitric oxide in inflammatory reactions.

FEMS Immunology and Medical Microbiology, 51(3), 443-452.

https://doi.org/10.1111/J.1574-695X.2007.00329.X 